\title{
Ryszard Czyszkiewicz
}

Szczecińskie Towarzystwo Socjologiczne

\section{Wybory w regionie zachodniopomorskim i w regionie podkarpackim. „Specyfika” Ziem Zachodnich}

STRESZCZENIE W artykule przedstawiono zróżnicowanie zachowań wyborczych mieszkańców dwóch regionów Polski - województwa zachodniopomorskiego i województwa podkarpackiego. Są to regiony najbardziej od siebie oddalone w sensie przestrzennym, ale pod względem podstawowych cech społeczno-ekonomicznych zamieszkujące je społeczności prawie zupełnie się nie różnią. Mimo to wyniki każdorazowo przeprowadzanych wyborów (przede wszystkim do Sejmu RP) okazują się diametralnie odmienne, a nawet przeciwstawne. W artykule znajdują się przykłady tych odmienności, podjęta jest także próba wyjaśnienia przyczyn zróżnicowania zachowań wyborczych i wskazania ich konsekwencji w postaci funkcjonowania utrzymywania się dwóch „terytorialnych plemion" o odmiennych systemach wartości.

\section{Wstęp}

Członkowie społeczeństwa różnią się w swoich poglądach politycznych. Różnice te mogą być koniunkturalne, ale równie często mogą stanowić rezultat ugruntowanych, utrwalonych
SŁOWA KLUCZOWE

REGION, WYBORY, ZACHOWANIA WYBORCZE, KLIMAT POLITYCZNY 
postaw. Jednym z wymiarów takiego ugruntowania postaw politycznych (manifestowanych w wyborach) jest ich zróżnicowanie terytorialne (geograficzne). Studia nad terytorialnym zróżnicowaniem wyników wyborów prowadzone w odniesieniu do wyborów w Stanach Zjednoczonych wskazują na ich stosunkową trwałość i niezmienność, powodowaną m.in. silnymi więziami lokalnymi, wspólnotą losów zbiorowości wyborców oraz sposobami kształtowania się opinii publicznej (Anderson 2010). W studiach szczegółowych nad regionami USA wskazuje się na rolę zachowań wyborczych jako elementu spajającego społeczności i jednocześnie dystynktywnego w stosunku do społeczności z innych stron kraju (Teixeira 2012).

Uwagi o terytorialnym zróżnicowaniu wyników wyborów (parlamentarnych) w Polsce po raz pierwszy pojawiły się już w pracy poświęconej analizie wyborów z 1989 roku. A. Florczyk i T. Żukowski (1990) przedstawili wtedy „geografię obywatelstwa”, ujawnioną przez frekwencję w tych wyborach oraz wyniki uzyskane z jednej strony przez obóz PZPR, a z drugiej przez obóz „Solidarności”. Autorzy ci zauważyli, że frekwencja wyborcza była wyższa, a jednocześnie poziom poparcia dla „Solidarności” był większy w regionach (województwach), w których:

po pierwsze: ludzie liczniej chodzą do kościoła (...) oraz istnieją tradycje ludowej opozycyjności z lat tworzenia systemu;

po drugie: integracja społeczna jest na wyższym niż przeciętny poziomie, zaś stopień kolektywizacji gospodarki rolnej jest niski (Florczyk, Żukowski 1990: 280).

Najważniejszym stwierdzeniem autorów było to, które mówiło, że zachowania polityczne Polaków mają swoje źródła nie tylko i nie tyle w cechach pozycji zawodowej lub poziomu życia, lecz wynikają ze zróżnicowania kulturowo-historycznego, a w szczególności z zachowanych regionalnych wzorców tradycji demokratycznej (Florczyk, Żukowski 1990: 281). W rezultacie oddziaływania szeregu procesów i zjawisk historycznych (granice zaborów, migracje z przełomu XIX i XX wieku, zasiedlanie Ziem Odzyskanych, opór przeciwko nowemu systemowi społeczno-politycznemu po II wojnie światowej) terytorium Polski i jej społeczeństwo zróżnicowały się znacząco, jeśli chodzi o popieranie „starych” i „nowych” sił politycznych. Tym nowym siłom - „Solidarności” - swego poparcia udzieliły:

Galicja oraz mieszkańcy Podlasia, Lubelszczyzny, Warszawy oraz Dolnego Śląska - najlepiej społecznie zintegrowanej i słabiej skolektywizowanej części Ziem Zachodnich. Władze partyjne i państwowe mogły liczyć na Wielkopolskę (lojalizm pruski czy nieufność wobec nadmiernego radykalizmu ruchu protestu?) oraz zdezintegrowane i skolektywizowane Pomorze Zachodnie, Ziemię Lubuską, Warmię, Mazury i Zagłębie Dąbrowskie - znane jeszcze sprzed wojny z silnych wpływów komunistycznych (Florczyk, Żukowski 1990: 282).

W podobny sposób poprowadził swoją analizę J. Raciborski (1997). Podobnie jak jego poprzednicy, zauważa on znaczącą odmienność wzorów głosowania między poszczególnymi regionami Polski, znajdując dla nich wytłumaczenie w postaci odmiennych tradycji kulturowo-historycznych. Granice tych tradycji wyznaczane są granicami rozbiorów (Raciborski 1997: 157). Jeszcze inną rzeczywistością są Ziemie Odzyskane. J. Raciborski zauważa, że mieszkańcy tych obszarów częściej popierali Sojusz Lewicy Demokratycznej niż inne ugrupowania polityczne. Sprzyjać temu miała względna jednorodność tego obszaru 
z punktu widzenia czynników społeczno-demograficznych i losów historycznych. Będące rezultatem tych procesów poziomy urbanizacji, odmienny kształt rolnictwa i odmienny obraz społeczny wsi faworyzowały ugrupowania lewicowe.

Teoria „zaborowa” została również przyjęta przez M. Kowalskiego, służąc mu do wysunięcia tezy o „pewnej trwałości polskiej sceny politycznej oraz o prawidłowościach rządzących przestrzennym rozmieszczeniem wpływów poszczególnych opcji” (Kowalski 2000: 30). W wynikach (i frekwencji) każdych organizowanych (do roku 1998) wyborów (prezydenckich, parlamentarnych i samorządowych) widział odzwierciedlenie:

(...) różnic między regionalnymi grupami etnicznymi a resztą społeczeństwa, zróżnicowanie społecznogospodarcze wynikające z opozycji duże miasta - reszta kraju oraz zaszłości historyczne (dziedzictwo rozbicia ziem polskich w latach 1772-1918, przyłączenie Ziem Zachodnich) (Kowalski 2000: 34).

W konsekwencji i w wynikach badań tego autora, i w wynikach badań wszystkich innych autorów posługujących się teorią „zaborową” odnotowuje się odmienne wzory głosowania mieszkańców dawniejszej Galicji (zabór austriacki), dawniejszej „Kongresówki” (zabór rosyjski), Wielkopolski i Pomorza (zabór pruski). Niezależnie od granic rozbiorowych, wyspami własnych, swoistych wzorów głosowania są grupy narodowościowe (mniejszość niemiecka na Śląsku i białoruska na Podlasiu), etniczne (Kaszubi, Ślązacy) oraz oczywiście zbiorowości zasiedlające Ziemie Zachodnie - ziemie, generalnie rzecz biorąc, nigdy wcześniej nieznajdujące się w granicach państwa polskiego i z tego powodu niemogące być przedmiotem żadnego zaboru.

Powstaje jednak pytanie, czy odrębność zachowań wyborczych mieszkańców tych regionów może oznaczać wypracowanie własnego, całkowicie nowego wzoru. M. Kowalski (2000) zauważa, że Ziemie Zachodnie zostały zasiedlone głównie przez ludność z byłego zaboru rosyjskiego (Kongresówki), co w pewnym stopniu upodabnia jej zachowania wyborcze do tych notowanych we wschodniej Polsce (np. stosunkowo niska frekwencja, poparcie dla opcji raczej lewicowej niż prawicowej, choć nie oznacza to takiego samego poparcia dla opcji ludowej - na Zachodzie znacznie większym uznaniem cieszy się opcja liberalna). Zachowania wyborcze mieszkańców Ziem Zachodnich (a szczególnie Pomorza Zachodniego), choć podobne, nie muszą wszakże być całkowicie tożsame z zachowaniami mieszkańców dawnej Kongresówki, bo istotną część przesiedleńców stanowili także mieszkańcy dawniejszego zaboru pruskiego - szczególnie z Wielkopolski. Co więcej, w wielu wypadkach tworzyli oni wyselekcjonowane i dobrze zorganizowane grupy pionierów, majacych za zadanie odbudowę i uruchomienie infrastruktury miejskiej (społecznej, materialnej, administracyjnej, przemysłowej itp.) na nowych terytoriach - stanowili zatem wpływową „elitę" przynajmniej w środowiskach miejskich (Dulczewski, Kwilecki 1962), co miało „w jakimś sensie" (Kowalski 2000: 52) wpływ na upodabnianie się społeczeństw Ziem Zachodnich i Wielkopolski.

Ale samo zamieszkiwanie $w$ danym regionie i oddalenie w przestrzeni od innych regionów nie może jednak być wystarczającym wyjaśnieniem różnic w zachowaniach wyborczych. Można, a nawet należy przyjąć, że mieszkańcy takich odseparowanych obszarów różnią się pewnymi innymi ważnymi cechami, będącymi rzeczywistymi przyczynami dokonywania odmiennych wyborów. Z tych czynników wyróżnić można dwie generalne grupy. Pierwsza związana jest z tradycjonalizmem, a dokładniej rzecz biorąc, z zasiedziałością społeczności na zamieszkiwanych przez nie terenach. Zasiedziałość to trwałość i ciągłość pokoleń 
w obrębie tej samej lub tych samych jednostek osiedleńczych. Oznacza to ciągłość tkanki i więzi społecznych, także norm i wartości, będących przedmiotem wpajania i kontroli ze strony względnie niezmiennego otoczenia społecznego. Przeciwieństwem tego stanu będzie brak zasiedziałości, rozumiany jako stosunkowo krótki czas zamieszkiwania na danym obszarze. Społeczności „niezasiedziałe” powstają i asymilują się w wyniku ruchów migracyjnych, tworzących skupienia osób wywodzących się z różnych ziem, charakteryzujących się różnicami kulturowymi, językowymi, obyczajowymi, także różnicami w doświadczeniach historycznych itp. Są to skupienia społeczne, w ramach których wchodzące w ich skład jednostki i grupy nie mają szans na narzucenie swych norm i wartości jako dominujących, nie mają także szans na zachowanie ich w niezmienionej postaci, czyli w takiej, w jakiej one były w czasie przybycia tych grup do nowego miejsca. Oczywiście jest to dychotomia poprowadzona „grubą kreską”, nieuwzględniająca tego, iż nie są to części kraju zupełnie od siebie odizolowane, nieuwzględniająca też tego, że migracje i wymiana ludności trwały i trwają dalej zarówno między tymi dwoma obszarami, jak i wewnątrz nich (np. migracje ze wsi do miast, ale w ostatnich latach i w kierunku odwrotnym - migracje ze środowiska miejskiego do środowiska, jeśli nie typowo wiejskiego, to pozamiejskiego). Nawet jednak zdając sobie sprawę z oddziaływania szeregu czynników ujednolicających odległe od siebie społeczności (należy tu koniecznie wspomnieć o roli, jaką tu spełniają środki masowego przekazu), trzeba przyznać, że jest sprawą bezsporną, iż w swojej masie mieszkańcy obu wcześniej wyróżnionych obszarów za każdym razem, gdy tylko mają ku temu okazję, głosują odmiennie.

\section{Regiony zachodniopomorski i podkarpacki}

W celu zobrazowania owych różnic i zdania relacji z rzeczywistego ich wymiaru dokonane zostanie porównanie zestawień wyników głosowania w Zachodniopomorskiem (na który składają się dwa okręgi wyborcze - koszaliński i szczeciński) w latach 2001-2014 z wynikami, jakie zapadały w Podkarpackiem (okręgi wyborcze krośnieński i rzeszowski). Regiony te zostały dobrane celowo nie tylko dlatego, że są najbardziej od siebie oddalone terytorialnie, ale także dlatego, że w pełni reprezentują „tradycje” społeczeństwa zasiedziałego (podkarpackie) oraz powstałego z migracji, niezasiedziałego (zachodniopomorskie).

Punktem odniesienia dla wszystkich przedstawianych wyników wyborczych będą oczywiście wyniki całego kraju. Są one sumą wyników zapadających we wszystkich okręgach wyborczych, a każdy z nich z osobna oczywiście różni się w mniejszej lub większej mierze od wyników krajowych. Źródłem wszystkich danych odnoszących się do wyników wyborów są oficjalne zestawienia przedstawiane przez Państwową Komisję Wyborczą.

Przede wszystkim należy dokonać zestawienia podstawowych wskaźników charakteryzujących społeczności obu regionów. Jako punkt odniesienia przyjęto rok 2013, a dane pochodzą z roczników statystycznych obu regionów (2013), „Diagnozy społecznej 2013”, wyników Narodowego Spisu Powszechnego 2011 oraz zasobów Zakładu Ubezpieczeń Społecznych (2013).

Liczebność zbiorowości podkarpackiej jest większa niż zbiorowości zachodniopomorskiej. Ta druga jest przy tym w o wiele większym stopniu zbiorowością miejską - poziom urbanizacji jest zresztą w tym regionie najwyższy w skali kraju. Innymi cechami dystynktywnymi są te związane z dochodami, produktywnością i aktywnością zawodową swoich członków. Społeczność zachodniopomorska jest bardziej aktywna zawodowo, charakteryzuje się nieco niższym poziomem bezrobocia, ma większy wkład w PKB kraju (w przeliczeniu 
na jednego mieszkańca), odbiera też większe za to „nagrody” - wyższe dochody oraz wyższe świadczenia społeczne. Ostatnią wreszcie znaczącą różnicą między obu społecznościami jest poziom „wykorzystania elektoratu”, czyli inaczej mówiąc - frekwencja wyborcza (tutaj w wyborach do sejmików wojewódzkich w 2014 roku).

Tabela 1

Podstawowe wskaźniki charakteryzujące społeczności regionów zachodniopomorskiego i podkarpackiego

\begin{tabular}{|c|c|c|}
\hline \multirow[t]{2}{*}{ Czynnik } & \multicolumn{2}{|c|}{ Region (województwo) } \\
\hline & zachodniopomorski & podkarpacki \\
\hline Liczba ludności & 1722739 & 2128687 \\
\hline Urbanizacja/ruralizacja & $69,8 \% / 31,2 \%$ & $41,4 \% / 58,6 \%$ \\
\hline Feminizacja & $51,3 \%$ & $51,0 \%$ \\
\hline Wiek 20-34 lat & $22,6 \%$ & $23,8 \%$ \\
\hline Wiek 65-69 lat & $14,3 \%$ & $14,2 \%$ \\
\hline Wykształcenie wyższe (2011) & $14,5 \%$ & $16,6 \%$ \\
\hline Wskaźnik aktywności zawodowej & $60,3 \%$ & $56,8 \%$ \\
\hline Wskaźnik pracujących & $53,0 \%$ & $49,3 \%$ \\
\hline Wskaźnik bezrobocia & $11,8 \%$ & $13,2 \%$ \\
\hline Odsetek emerytów i rencistów & $20,9 \%$ & $21,5 \%$ \\
\hline Średnia wysokość emerytury/renty & 1793,88 zł & $1600,77 \mathrm{zł}$ \\
\hline Średni dochód netto miesięcznie & 1419,93 zł & $1089,94 \mathrm{zł}$ \\
\hline Wkład w PKB kraju & $3,8 \%$ & $3,9 \%$ \\
\hline PKB na 1 mieszkańca & $36324 \mathrm{zł}$ & 30706 zł \\
\hline $\begin{array}{l}\text { Liczba wyborców/ liczba głosujących } \\
(2014)\end{array}$ & 1352 418/595911 & 1717 640/869 409 \\
\hline Stopień wykorzystania elektoratu (2014) & $44,1 \%$ & $50,6 \%$ \\
\hline
\end{tabular}

Źródło: Bank Danych Lokalnych, www.stat.gov.pl, obliczenia własne; Państwowa Komisja Wyborcza, www.pkw.pl, obliczenia własne.

Poziomy frekwencji wyborczej w perspektywie wyborów do Sejmu RP przeprowadzonych w latach 2001-2011 nie wydają się jednak wskazywać na stabilne wzory mówiące o większej aktywności wyborców z jednego regionu w porównaniu z poziomami aktywności wyborców drugiego regionu. Jeśli można mówić o jakiejś prawidłowości, to o takiej, która wskazuje na ujednolicanie się wzoru udziału w wyborach. W wyborach w latach 2007 i 2011 brały udział podobne odsetki osób zamieszkujących region podkarpacki i zachodniopomorski. Tym, co jednak charakteryzuje szczególnie wyborców z regionu zachodniopomorskiego, jest znacznie większa niestabilność notowana w całym okresie 20012011. Napływy lub odpływy liczby wyborców, pragnących oddać swój głos w poszczególnych wyborach, były znacznie większe niż było to w przypadku wyborców z regionu podkarpackiego. 


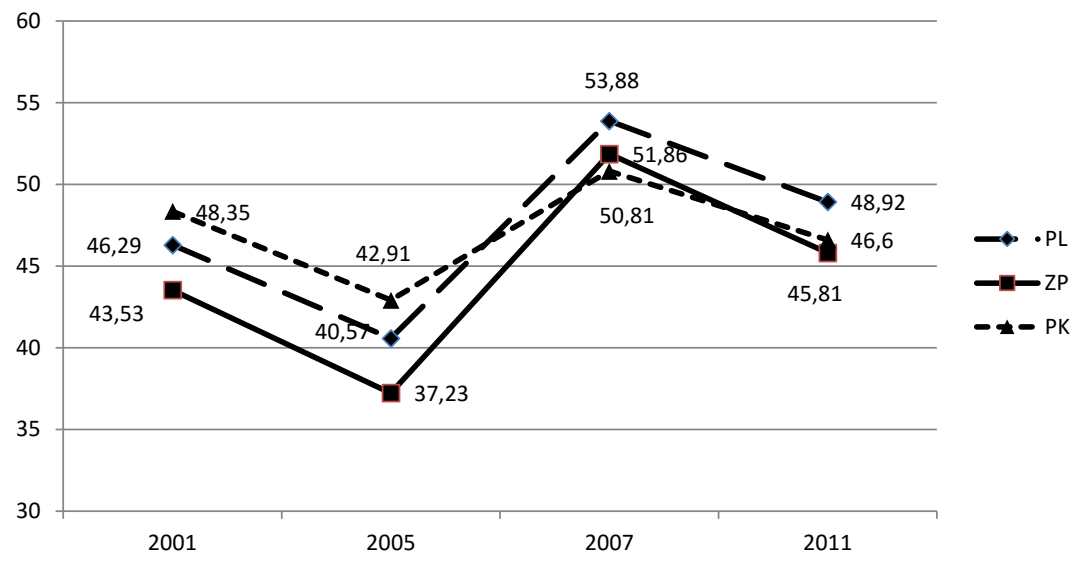

Rysunek 1. Frekwencja w wyborach do Sejmu RP w latach 2001-2011

Źródło: dane PKW.

Poziomy kompetencji, w postaci odsetków głosów ważnych, nie wykazywały prawie żadnych różnic.

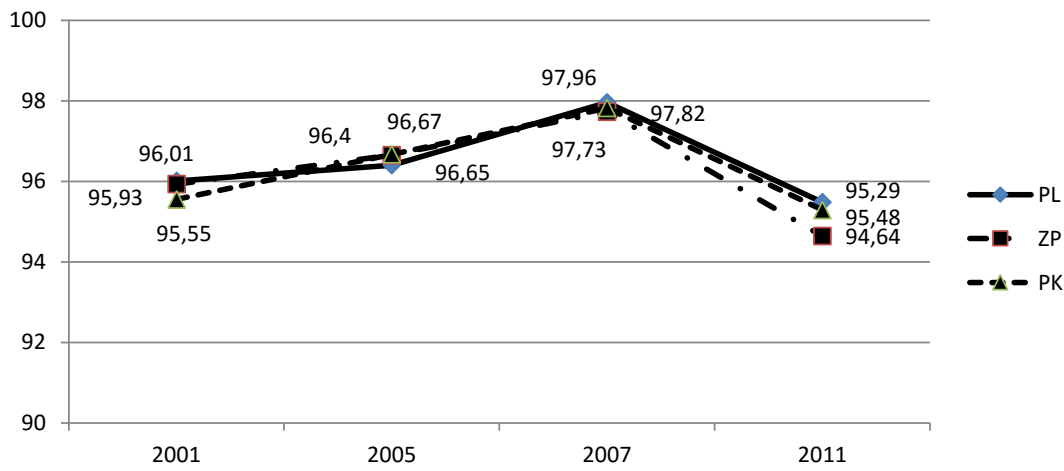

Rysunek 2. Odsetki głosów ważnych w wyborach do Sejmu RP w latach 2001-2011

Źródło: dane PKW.

Na aktywność wyborczą w różnych stronach Polski można spojrzeć także i poprzez pryzmat możliwych opcji, będących przedmiotem wyboru. Okręg rzeszowski stopniowo ograniczał swoją aktywność wraz ze wzrostem znaczenia opcji lewicowych i liberalnych. Frekwencja wyborcza wyznaczana jest nie tylko przez wzory tradycyjnego uczestnictwa, ale także poprzez wolumen sił politycznych, które można i które warto poprzeć. Jeśli ich brakuje, zaczyna brakować w ogóle motywacji do przejawiania większej aktywności wyborczej, tj. do udania się do lokalu wyborczego, w którym i tak niewiele jest do zrobienia przy braku odpowiednich dla siebie faworytów. Skumulowana (nieuwzględniająca wartości dodatnich i ujemnych) różnica między ogólną frekwencją w kraju i w Zachodniopomorskiem dla lat 2001-2011 wynosi 11,23, natomiast w Podkarpackiem 9,79. Należy tu jednak 
zaznaczyć, że odmienność podkarpackiego wzoru wyznaczana była większym udziałem w wyborach w latach 2001 i 2005, a mniejszym w wyborach w latach 2007 i 2011, w przypadku wzoru zachodniopomorskiego wynikała ona z nieznacznej, ale jednak zawsze niższej frekwencji niż frekwencja obliczana dla całego kraju.

Odmienne wzory zachowań wyborczych w postaci odmiennych poziomów frekwencji nie wyczerpują jednak możliwego zakresu różnic. Odnoszą się one nie tylko do gotowości do głosowania, ale także do skłonności do głosowania na konkretne partie lub opcje polityczne.

W przedstawieniu tych różnic pomocne będzie zobrazowanie wyników osiągniętych przez poszczególne partie zgłaszające listy swych kandydatów. Oddzielnie zostaną zaprezentowane wielkości dla całego kraju, a następnie dla regionów zachodniopomorskiego i podkarpackiego.

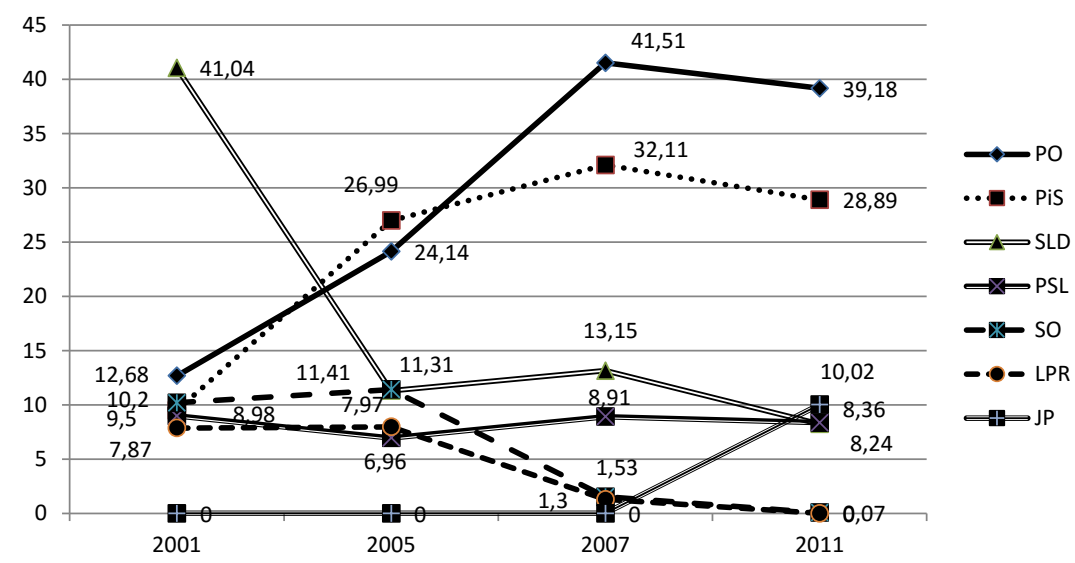

Rysunek 3. Wyniki wyborów do Sejmu RP w latach 2001-2011 dla Polski

Źródło: dane PKW.

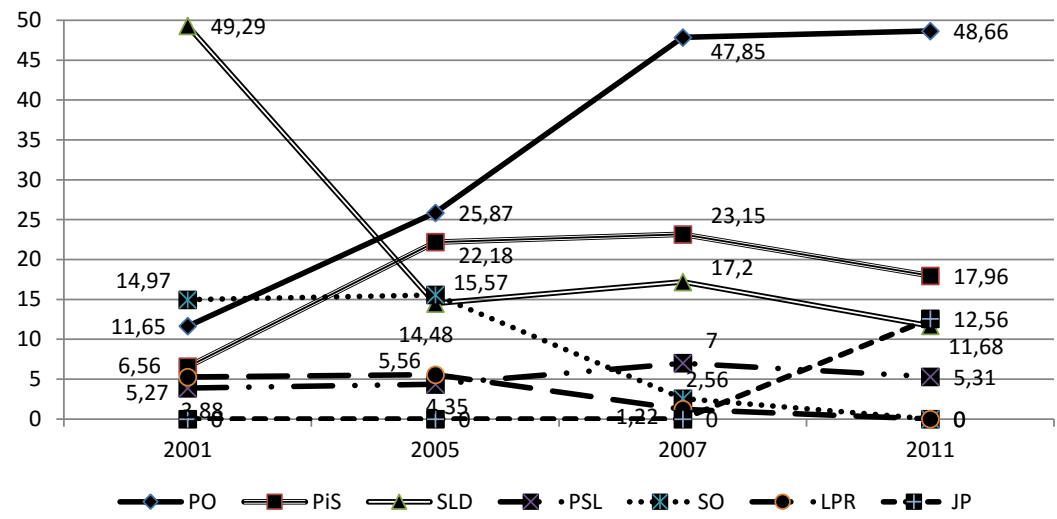

Rysunek 4. Wyniki wyborów do Sejmu RP w latach 2001-2011 dla regionu zachodniopomorskiego

Źródło: dane PKW. 


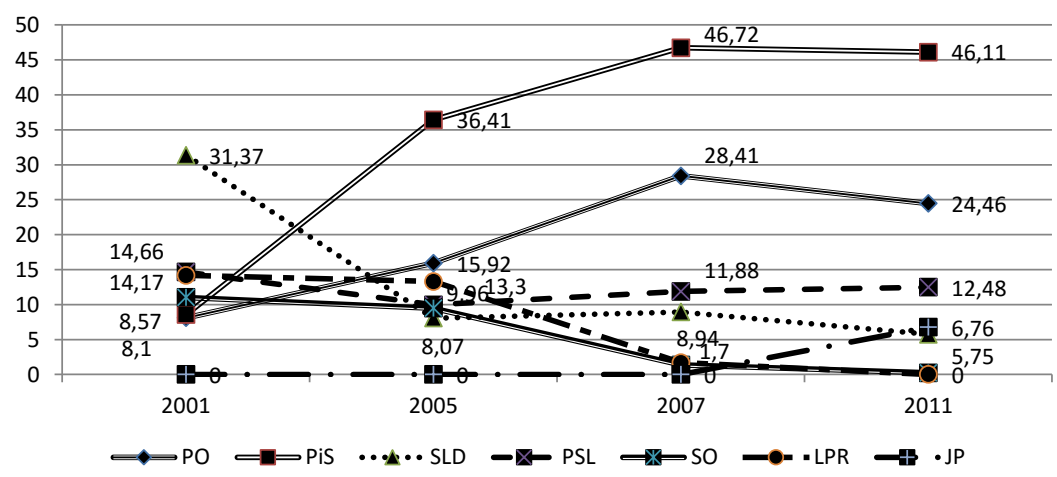

Rysunek 5. Wyniki wyborów do Sejmu RP w latach 2001-2011 dla regionu podkarpackiego Źródło: dane PKW.

Zarówno w odniesieniu do całego kraju, jak i obydwu regionów - zachodniopomorskiego i podkarpackiego - znamienne były wydarzenia roku 2005. Oznaczały one dekompozycję dotychczasowego układu sił, charakteryzującego się wyraźną dominacją SLD, oraz poszukiwanie na miejsce dotychczasowego hegemona nowych sił wartych poparcia. Między obu regionami istnieją jednak dwie istotne różnice: (1) w obu nowymi siłami okazały się zupełnie inne partie - PO w Zachodniopomorskiem i PiS w Podkarpackiem; (2) nieco inna ich jest sytuacja. W województwie zachodniopomorskim pozycja PO zasługuje na miano hegemonistycznej, w województwie podkarpackim pozycję dominującą uzyskał PiS, ale jednak nie zasługuje na miano hegemona ze względu na lepsze wyniki PO. Wyborcy zachodniopomorscy postępują w najprostszy możliwy sposób, zmieniając po prostu hegemona. Taką większą dyspozycję ku „niestałości” trudniej zauważyć w przypadku wyborców z regionu podkarpackiego.

Pomocne w tym względzie okazać się może zestawienie wyników wyborów parlamentarnych (do Sejmu RP) z wynikami wyborów do sejmików wojewódzkich w latach 20072011 (na rysunkach symbol K oznacza wybory szczebla krajowego, czyli do Sejmu, symbol S - wybory szczebla samorządowego, czyli do sejmików).

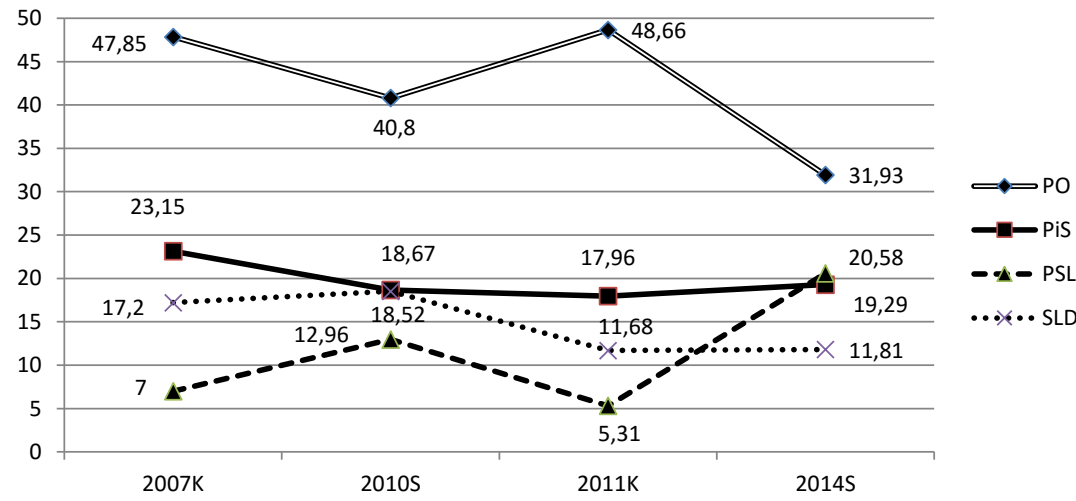

Rysunek 6. Wyniki wyborów do Sejmu RP i do sejmiku wojewódzkiego - region zachodniopomorski

Źródło: dane PKW. 


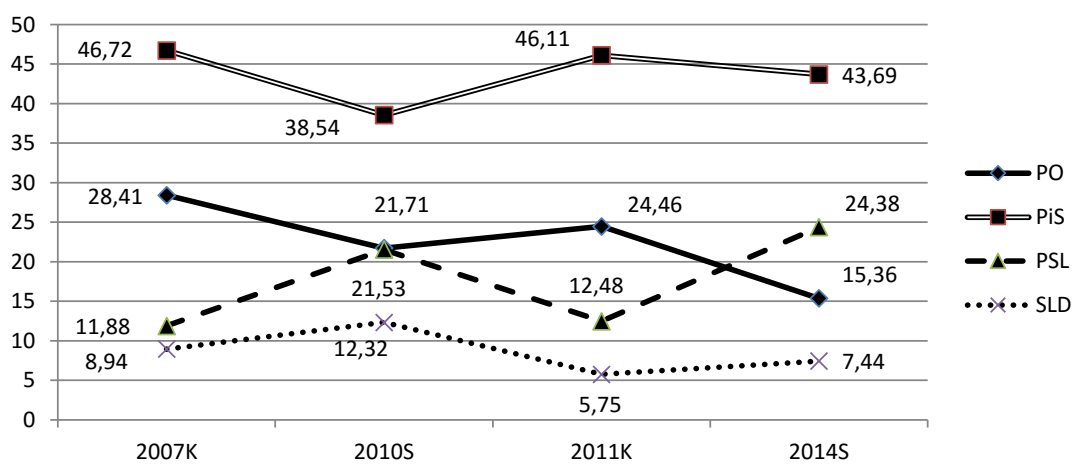

Rysunek 7. Wyniki wyborów do Sejmu RP i do sejmiku wojewódzkiego - region podkarpacki

Źródło: dane PKW.

W Zachodniopomorskiem pozycja hegemona (PO) znacząco słabnie, zwłaszcza w wyborach samorządowych. W Podkarpackiem pozycja PiS, niezależnie od rodzaju wyborów, pozostaje stabilna. Być może wyborców z regionu zachodniopomorskiego należałoby uznać za wyborców w większym stopniu racjonalnych, tzn. kierujących się w swoich decyzjach oceną skuteczności danych aktorów w zależności od sceny, na której występują. Platforma Obywatelska jest właściwa ze względu na sprawy krajowe, ale w kwestiach regionu nie sposób nie zauważyć rosnącego stopnia poparcia dla PSL. Wyborcy podkarpaccy są stali w swoim poparciu dla PiS, ale zmieniają poparcie dla PO i PSL, gdy przychodzi do wskazywania ważnych sił w regionie.

Nauki politologiczne oraz socjologia polityki zwykły poświęcać wiele uwagi pozycjonowaniu partii i ugrupowań politycznych na skali wartości i interesów. Punktem odniesienia jest tu zawsze stopień (lub w ogóle sam fakt) obecności państwa w regulowaniu zachowań obywateli, leżących w zakresie ich światopoglądów ideologicznych, i zakresów wolności gospodarowania. Wyborcy, podejmując decyzje o swoim głosie, decydują w gruncie rzeczy o tym, jakie wizje i kształty ich wspólnoty obywatelskiej, narodowej wydają się im pożądane i właściwe. Za takim czy innym rozwiązaniem opowiada się zwykle więcej niż jedna partia, niektóre z nich uzyskują wręcz śladowe stopnie poparcia, inne, nie wygrywając, stanowią istotne wsparcie dla nurtu reprezentowanego przez partie zwycięskie (czasami wchodząc z nimi w koalicje). Przyjęcie takiego zróżnicowania partii i ich programów pozwala nie tylko na dokonanie dość klarownego i szeroko przyjętego sposobu pozycjonowania ugrupowań politycznych (Shafer, Spady 2014), ale także na wskazanie wątków uniwersalnych i komunitariańskich w poglądach kierujących decyzjami wyborców (Cześnik 2007).

W zakresie orientacji na określone wartości zbiorowości wyborców z regionów podkarpackiego i zachodniopomorskiego wydają się bardzo wyraźnie różnić. W przypadku tej drugiej zbiorowości mamy do czynienia z wyraźnym odpływem postaw faworyzujących znaczącą obecność państwa w procesach regulacji gospodarki. W przypadku regionu podkarpackiego zanik postaw etatystycznych jest również widoczny, ale nie następuje ani szybko, ani gwałtownie. Postawy liberalne w odniesieniu do gospodarki charakteryzujące wyborców z regionu zachodniopomorskiego nie muszą być jednak aż tak bardzo 
rozpowszechnione. Są one następstwem popierania jednej partii (PO) przy całkiem sporym poparciu dla innych „prorynkowych” partii (jak np. Ruch Palikota, Ruch Wyborców Janusza Korwin-Mikke).

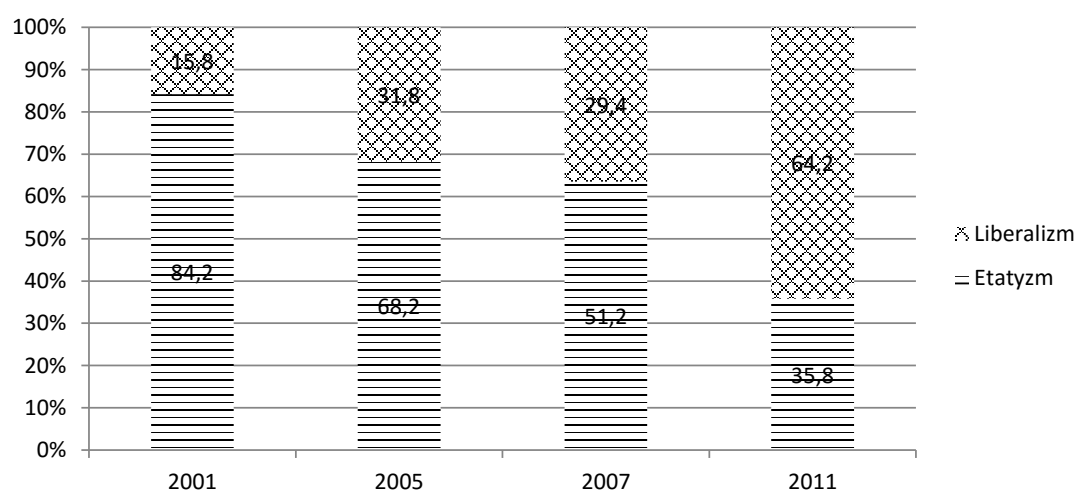

Rysunek 8. Stopień poparcia dla opcji liberalnych i etatystycznych w gospodarce w Zachodniopomorskiem

Źródło: obliczenia własne na podstawie danych PKW.

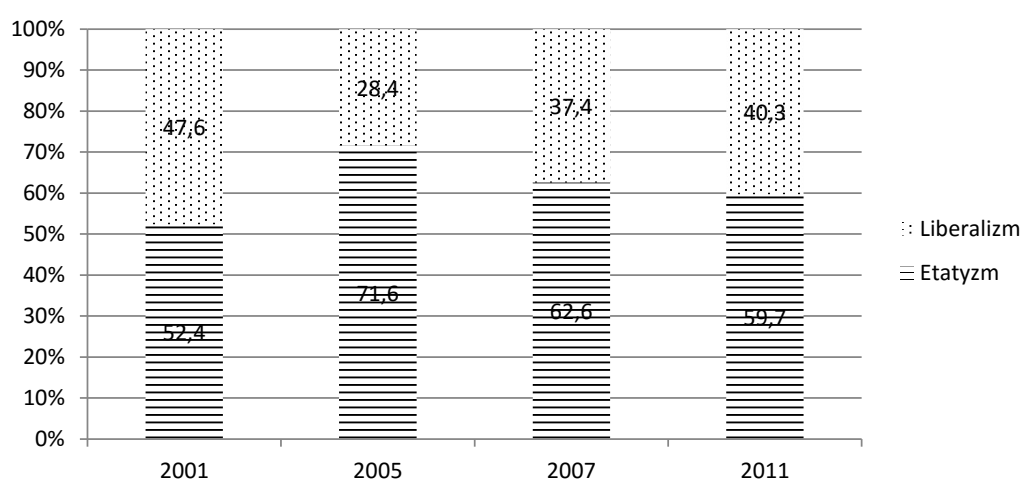

Rysunek 9. Stopień poparcia dla opcji liberalnych i etatystycznych w gospodarce w Podkarpackiem

Źródło: obliczenia własne na podstawie danych PKW.

W przypadku kwestii światopoglądowych mamy do czynienia z prawie identyczną sytuacją. Wyborcy z regionu zachodniopomorskiego optują za większym liberalizmem, wyborcy z regionu podkarpackiego są w większej mierze przywiązani do jakiegoś „centralnego” (etatyzm) spojrzenia na te kwestie. 


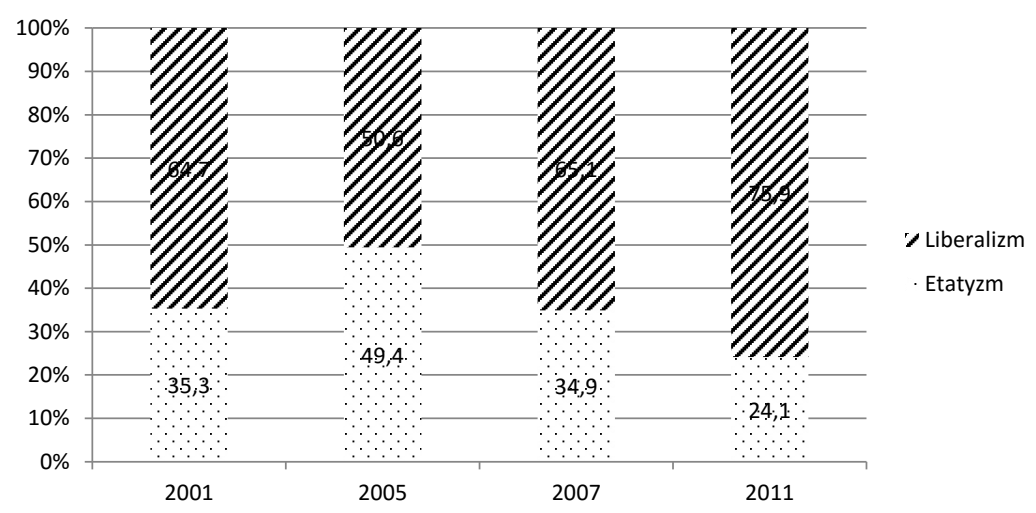

Rysunek 10. Stopień poparcia dla opcji liberalnych i etatystycznych w kwestiach światopoglądowych w Zachodniopomorskiem

Źródło: obliczenia własne na podstawie danych PKW.

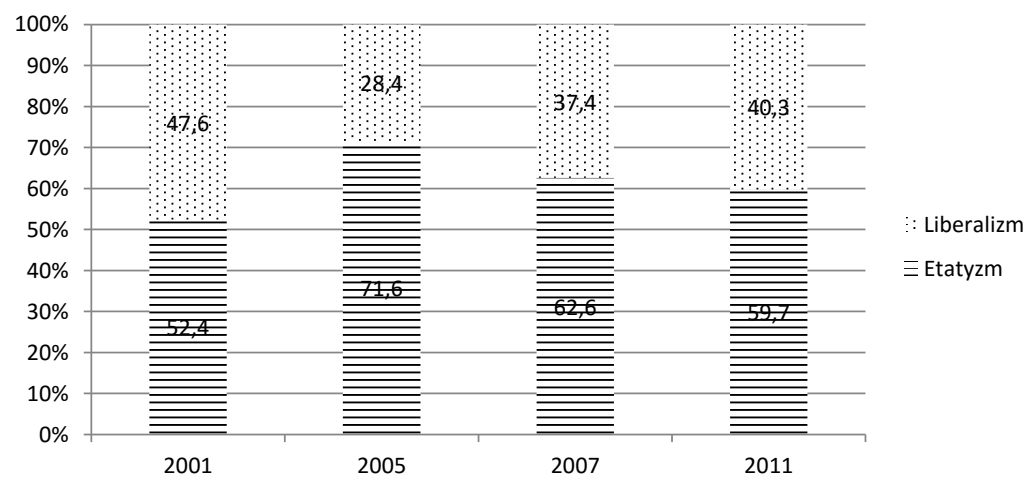

Rysunek 11. Stopień poparcia dla opcji liberalnych i etatystycznych w kwestiach światopoglądowych w Podkarpackiem

Źródło: obliczenia własne na podstawie danych PKW.

Autonomiczność postaw liberalnych bądź etatystycznych w przypadku obu zbiorowości może budzić pewne zastrzeżenia i wątpliwości. Wiążą się one z rozstrzygnięciem dylematu: czy sukces uzyskują partie trafnie „odgadujące” nastawienia wyborców, czy też wyborcy głosują na „popularność” danych partii, niezależnie od ich programów, udzielając tym samym wsparcia określonym programom bez większego ich zrozumienia. W wyborach w roku 2005, wygranych przez PiS, mieliśmy do czynienia z ogólnym zahamowaniem postaw liberalnych, w wyborach w latach 2007 i 2011 sytuacja, w związku ze zwycięstwami $\mathrm{PO}$, była już zupełnie inna.

Na tym tle wyborcy zachodniopomorscy tworzą obraz zbiorowości bardziej zdeterminowanej w swych jednolitych poglądach i podejmowanych decyzjach. Zawsze (a przynajmniej w latach 2001-2011) opowiadali się w większości po stronie jednego aktora sceny wyborczej, a przy tym, jak się okazywało, aktora zwycięskiego. Być może to oni 
współtworzą główny nurt (mainstream) polskiej areny politycznej, a w każdym razie bezpiecznie w nim płyną, mogąc pozwolić sobie na silne poczucie uczestniczenia w gronie zwycięzców. W tym sensie bariera między zbiorowością zachodniopomorską a podkarpacką (w kontekście wyborów politycznych) rysuje się jako silna i być może nie do przezwyciężenia. Jedni „stale” (w granicach rozpatrywanego okresu) współtworzą obóz „wygranych”, drudzy „stale” współtworzą obóz „przegranych”.

Nie jest to jednak obraz do końca prawdziwy. Przekonują o tym wyniki wyborów samorządowych (do sejmiku wojewódzkiego) w roku 2014. Przebiegają one w granicach obwodów skupiających kilka sąsiadujących powiatów. Można jednak na wyniki tych wyborów spojrzeć z innej perspektywy, oddzielnie zliczając głosy udzielane przez mieszkańców wsi i mieszkańców miast. Jest to zabieg sztuczny i niepociągający za sobą oczywiście jakiegokolwiek podziału mandatów. Pozwala jednak przedstawić zróżnicowania zachodzące w - wydawałoby się - dość jednolitych blokach wyborców głosujących „przeważnie”, „w większości” itp., na jedną tylko partię czy ugrupowanie polityczne. I jak wcześniej przytaczane dane mówiły o znaczących barierach i różnicach między obu zbiorowościami wyborców (zachodniopomorską i podkarpacką), teraz rzucają nieco światła na łączące ich podobieństwa.

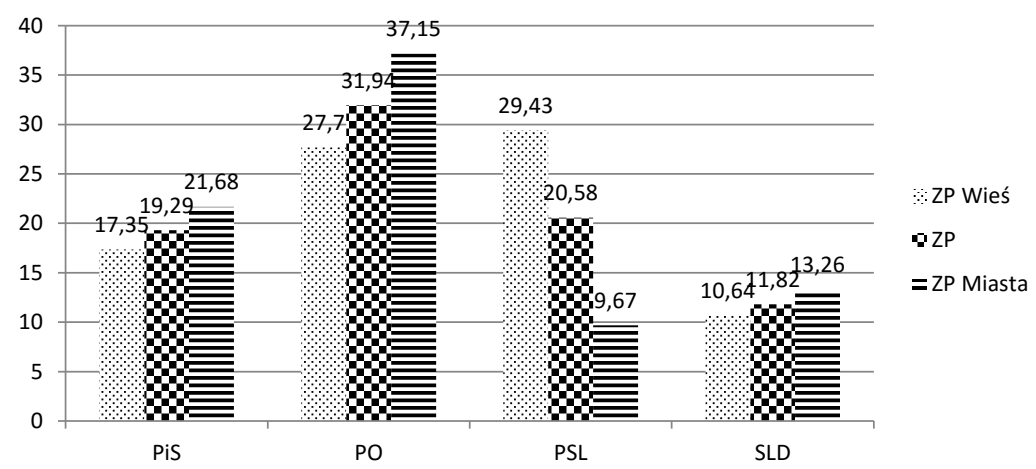

Rysunek 12. Głosy mieszkańców wsi i miast w wyborach do sejmiku wojewódzkiego w województwie zachodniopomorskim

Źródło: obliczenia własne na podstawie danych PKW.

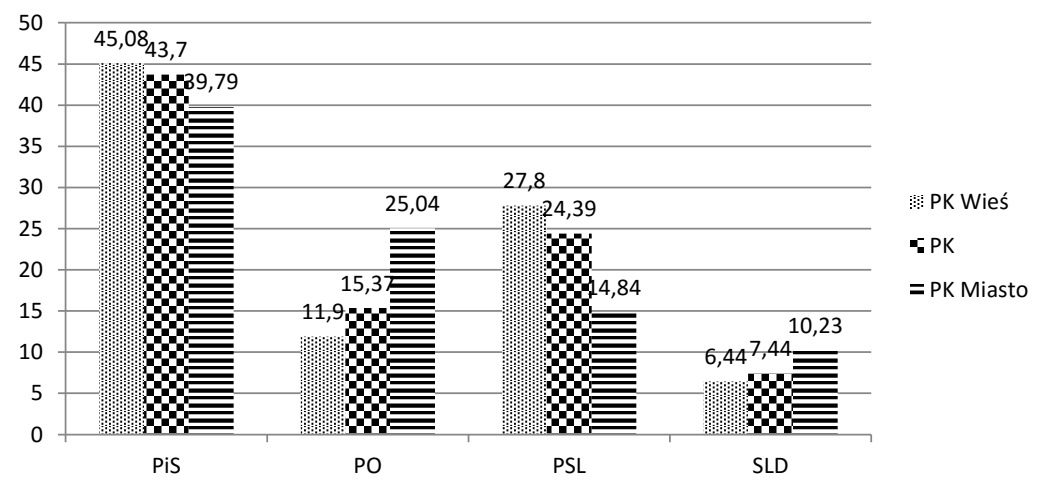

Rysunek 13. Głosy mieszkańców wsi i miast w wyborach do sejmiku wojewódzkiego w województwie podkarpackim

Źródło: obliczenia własne na podstawie danych PKW. 
Tym podobieństwem jest niezwykle silna pozycja PSL w środowiskach wiejskich, szczególnie w województwie zachodniopomorskim. Partia ta w tym województwie w środowiskach wiejskich bezapelacyjnie wygrała, osiągając nawet lepszy rezultat niż w województwie podkarpackim. Prowadzi to do istotnego pytania o różnice i podobieństwa między mieszkańcami obszarów wiejskich na zachodzie i wschodzie kraju. Ten drugi obszar uznawany jest w zasadzie za „tradycyjny” i z racji zaszłości historycznych bardziej skupiony wokół tradycyjnych sił politycznych (w tym i tych reprezentujących ruch ludowy, żeby nie powiedzieć chłopski). W Zachodniopomorskiem tradycje chłopskie i tradycje ruchu ludowego nie miały nigdy wielkich szans na rozwinięcie się, już znacznie większe szanse miały tradycje kolektywistycznej gospodarki rolnej oraz tradycje proletariatu wiejskiego (PGR-y). Do 2001 roku reprezentantem tych środowisk wydawał się SLD i prezydentura Aleksandra Kwaśniewskiego (Czyszkiewicz 2009). Po jej zakończeniu i po wyraźnym „krachu” doświadczonym przez SLD na to miejsce wkroczyła PO, ale w środowiskach wiejskich jednak PSL. Próbą odpowiedzi na pytanie, dlaczego tak się stało, byłoby stwierdzenie, że za sukcesem obu tych ugrupowań w środowiskach pozbawionych szerszej tradycji kulturowej i politycznej stoi większa sprawność instytucjonalna obu ugrupowań. „Racjonalność” wyborcy zachodniopomorskiego polegałaby w tym wypadku na trafniejszej ocenie korzyści obiecywanych (przynajmniej) przez tych, którzy starają się o jego głos.

$*$

W październiku 2015 roku odbyły się kolejne wybory parlamentarne, których wyniki zdają się kwestionować dotychczasowy (1991-2011) obraz polskiej geografii wyborczej - niemal we wszystkich regionach (województwach) zwycięstwo odniosła jedna partia (PiS), utrzymując swoją pozycję w regionach będących jej „bastionem” i zdobywając nowe - oprócz województw pomorskiego i właśnie zachodniopomorskiego. Nie jest to jednak wydarzenie bezprecedensowe w dziejach polskich wyborów - podobną przewagę zanotowało SLD w wyborach 2001 roku.

Uwzględniając wyniki wyborów parlamentarnych z 2015 roku i skupiając się tylko na osiągnięciach PO i PiS, rezultaty mogłyby wskazywać na istotne zmiany, które jednak nie wszędzie można zaobserwować. Pozycja PO w Podkarpackiem w 2015 roku odpowiada w zasadzie pozycji tej partii w 2001 roku. Z kolei pozycja PiS tylko niewiele poprawiła się w porównaniu z 2011 rokiem. W Zachodniopomorskiem natomiast pozycja obu głównych protagonistów ponownie przypomina tę z roku 2001, a także z 2005 - w zasadzie równowagę, aczkolwiek na innym poziomie uzyskanych głosów. W dłuższym czasie zmiany nie są zatem aż tak bardzo znaczące.

Najważniejsze jednak jest to, że PO i PiS nie wyczerpują spektrum możliwych wyborów. W wyborach uczestniczą inne partie, których programy i oferty, mimo różnego rozłożenia akcentów, można klasyfikować na osi liberalizmu i etatyzmu w sferze światopoglądów (oś wartości) oraz w sferze gospodarki (oś interesów). Za przedstawicieli opcji etatystycznych (w przypadku obu osi) można uznać PiS i PSL, z uwagi na głoszone hasła (narodowe itp.) za przedstawicieli etatyzmu w sferze światopoglądowej można uznać ruch Kukiz'15 (choć może to budzić pewne zastrzeżenia). Pozostali uczestnicy dyskursu wyborczego reprezentowali różnie wyważoną, ale jednak retorykę i programy liberalne w obu sferach. 


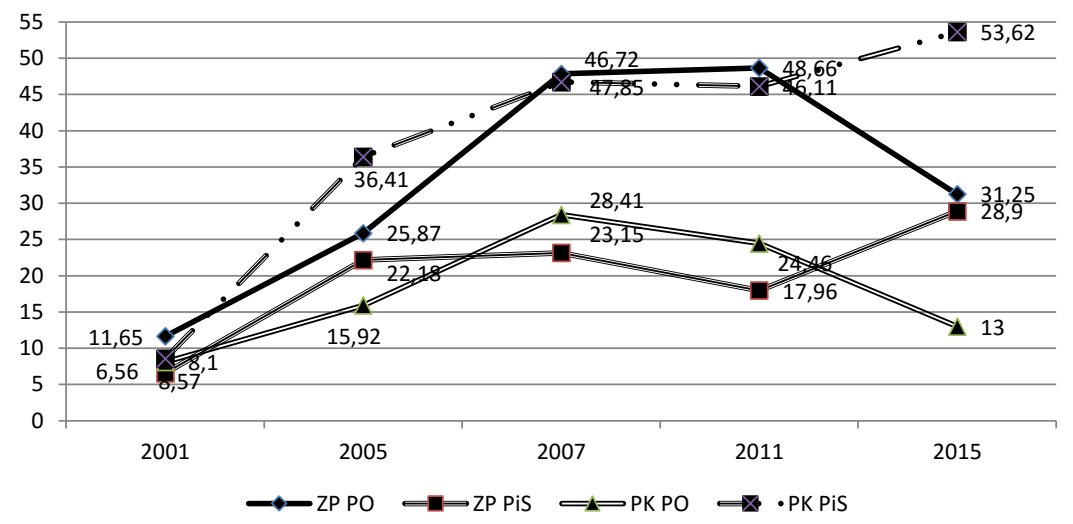

Rysunek 14. Wyniki wyborów do Sejmu RP w latach 2001-2015 w Zachodniopomorskiem (ZP) i Podkarpackiem (PK)

Źródło: dane PKW.

Orientacje w stosunku do takich przeciwstawień uzasadnia twierdzenie o trwałych różnicach w geografii wyborczej. Wybory nigdy nie były i nie są teatrem dwóch tylko aktorów. Wielu innych obecnych na scenie politycznej przedstawia oferty dające możliwość dywersyfikacji dokonywanych wyborów, zauważenia odmiennych akcentów w artykułowaniu wspólnych problemów, kwestii i pytań. W systemie demokratycznym wartością samą w sobie jest system partyjny, dopuszczający możliwość obecności i współzawodniczenia (ubiegania się o głosy) wielu podmiotów. Nie jest wartością istnienie lub nieistnienie, powodzenie lub niepowodzenie tej czy innej partii.

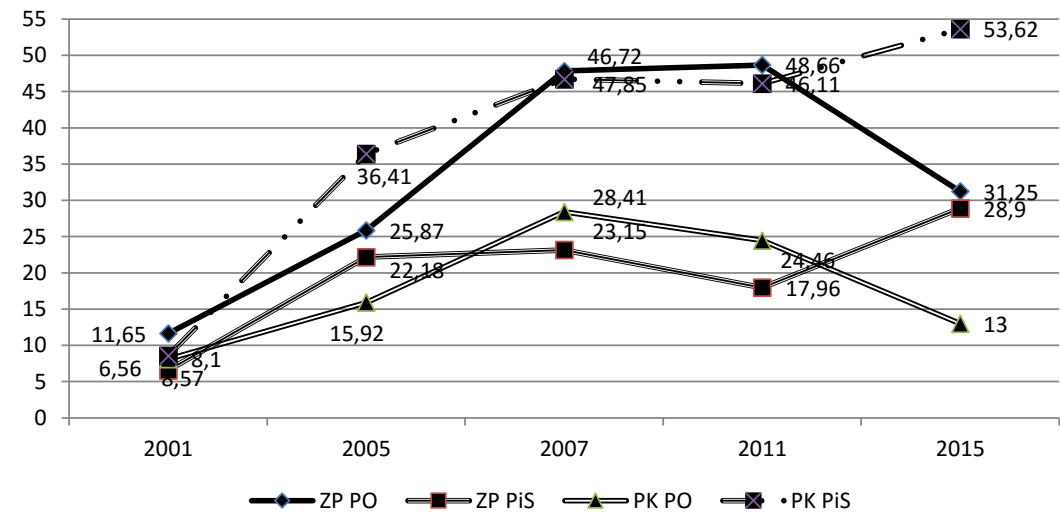

Rysunek 15. Poparcie dla opcji gospodarczych i światopoglądowych 2001-2015 w Zachodniopomorskiem (ZP) i Podkarpackiem (PK)

Źródło: obliczenia własne na podstawie danych PKW. 
Różnica między głosującymi społecznościami - zachodniopomorską i podkarpacką jest w dalszym ciągu istotna, aczkolwiek stale następują zmiany. Ta pierwsza społeczność jest bardziej otwarta na opcje etatystyczne, ta druga - na liberalne. Obecnie w największym stopniu wyrażają je z jednej strony PiS, z drugiej - PO. Jeśli jednak z jakiegoś powodu zabraknie jednej czy obu tych partii, na ich miejscu pojawią się inne, takie, które będą odpowiadać społecznemu „zapotrzebowaniu”, nawet jeśli będzie ono różne w różnych częściach kraju.

\section{Zakończenie}

Przedstawianie różnic w decyzjach wyborczych podejmowanych przez obywateli żyjących na przeciwległych krańcach państwa ma nie tylko wymiar ciekawostkowy. Wszak decyzje te są różne, a nawet zupełnie odmienne, właściwie od pierwszego momentu, w którym (przynajmniej częściowo w 1989 roku) obywatele Polski mieli możliwość uczestniczenia w wolnych wyborach. Paradoksalnie, ale różnice te zatarły się tylko raz - w 2000 roku - przy ponownym wyborze na prezydenta RP A. Kwaśniewskiego (choć istnieją ślady tych różnic w postaci mniejszego lub większego poparcia), wywodzącego się i z czasów, i z obyczaju jednolitego głosowania na jedną listę.

Ustawiczna odmienność podejmowanych decyzji wyborczych nie musi w obecnych czasach grozić wojną domową, w wielu państwach będących reakcją jednej części obywateli na wybór czyniony przez inną ich część (żeby wspomnieć chociażby wojny w Stanach Zjednoczonych w latach 60. XIX wieku czy wojnę domową w Hiszpanii w latach 30. XX wieku). Znamionują one jednak istnienie poważnego rozłamu, a przynajmniej nieciągłości postaw, zachowań oraz stojących za nimi wartości i norm, czy też ich brak. T. Zarycki (2002) w swoich analizach dotyczących zróżnicowania wyborczego obywateli Polski w latach 90. XX wieku pisał o wyraźnym ukształtowaniu się cleveage między „Centrum” i „Peryferium”. Polska i jej obywatele nie mieli pełnej możliwości podążać drogą wyznaczoną przez zachodnie demokracje. Na przeszkodzie stał brak własnego państwa (okres zaborów), a potem brak niezawisłego państwa (okres PRL-u). Z par przeciwieństw, wokół których toczył się dyskurs i w stosunku do których dokonywano wyborów - Kościół vs państwo, praca vs własność, centrum vs partykularyzm - aktualną dla polskiej rzeczywistości okazała się właściwie tylko ta ostatnia. We współczesnym ujęciu dotyczy ona modelu społeczeństwa obywatelskiego i jego relacji z modelem państwa. W szerszym kontekście dotyczy także kwestii kapitału i zaufania społecznego, o czym szeroko pisał wspomniany T. Zarycki (2002), a w odniesieniu do regionu zachodniopomorskiego również autor niniejszego tekstu (Czyszkiewicz 2006).

W tych kontekstach różne wybory dokonywane na przeciwległych krańcach Polski - region zachodniopomorski i region podkarpacki - można byłoby postrzegać jako elementy opowiadania się za odmiennymi wzorami życia publicznego, wypływającymi z odmiennych kształtów kapitału społecznego. Tym, co musi zwrócić szczególną uwagę, jest to, że brak przenikania się obu tych wzorów (patrząc z perspektywy terytorialnego rozkładu głosów na poszczególne opcje polityczne) wyklucza właściwie ich dyskurs i ścieranie się. Procesy te praktycznie nie występują. Pozwala to wręcz na sformułowanie tezy, iż mamy do czynienia raczej z dwoma „plemionami”, skupionymi wokół własnych totemów (systemów wartości i przekonań), niż ze społeczeństwem obywatelskim, dyskutującym o innych, na równi kluczowych sprawach publicznych. 


\section{LITERATURA}

America's New Swing Region. Changing Politics and Demographic in the Mountain West 2012, ed. R. Teixeira, Brooking Institution Press, Washington DC.

Anderson M.R. 2010, Community Identity and Political Behavior, Pallgrave MacMillian, New York.

Cześnik M. 2007, Partycypacja wyborcza w Polsce. Perspektywa porównawcza, Wydawnictwo Naukowe Scholar, Warszawa.

Czyszkiewicz R. 2006, Zachodniopomorski kapitał ludzki i kapitał społeczny, w: Energia Pomorza Zachodniego, II Kongres Zachodniopomorski, Fundacja Rozwoju Pomorza Zachodniego, Szczecin, s. 283-292.

Czyszkiewicz R. 2009, Rzeczpospolita z gminnego nadania. Zachowania wyborcze mieszkańców województwa szczecińskiego 1991-2007, Wydawnictwo Adam Marszałek, Toruń.

Dulczewski Z., Kwilecki A. 1962, Społeczeństwo wielkopolskie w osadnictwie Ziem Zachodnich, Wydawnictwo Poznańskie, Poznań.

Florczyk A., Żukowski T. 1990, Nowa geografia polityczna Polski, w: Wyniki badań - wyniki wyborów 4 czerwca 1989, red. L. Kolarska-Bobińska, P. Łukasiewicz, Z.W. Rykowski, PTS, Warszawa.

Kowalski M. 2000, Geografia wyborcza Polski, PAN, Instytut Geografii i Przestrzennego Zagospodarowania, Warszawa.

Raciborski J. 1997, Polskie wybory. Zachowania wyborcze społeczeństwa polskiego w latach 1989-1995, Wydawnictwo Naukowe Scholar, Warszawa.

Shafer B.E., Spady R.H. 2014, American Political Landscape, Harvard University Press, Cambridge-London.

Zarycki T. 2002, Region jako kontekst zachowań politycznych, Wydawnictwo Naukowe Scholar, Warszawa.

\section{ELECTIONS IN ZACHODNIOPOMORSKIE AND PODKARPACKE REGIONS. "SPECIFICITY" OF WEST TERRITORIES}

KEYWORDS REGION, ELECTIONS, ELECTORIAL BEHAVIOUR, POLITICAL CLIMATE
SUMMARY The article deals with the phenomenon of diversification of electoral votes between the inhabitants of two Polish regions - Zachodnioporskie and Podkarpackie regions. There is a huge distant between these two regions (in geographical sense) but the main socio-economic data describing both societies are of little difference. Nevertheless, the outcomes of every Parliamentary votes are largely different and even contrary in both regions. The article contains the samples of the differences, describes some explanations and points the consequences targeting on two "territorial tribes" showing contrary worlds of values. 